\title{
Reseña de DarTNelL, Lewis. Origins: How the Earth Made Us. Popular Science/History Collection. UK: Bodley Head. 352 pp. ISBN: 978-1-847-92435-3
}

José Lugo HubP

Instituto de Geografía, Universidad Nacional Autónoma de México

México

El libro Originis. How the Earth made Us, publicado en inglés el 31 de enero de 2019, contiene una introducción, nueve capítulos, una coda (conclusión), notas en 19 páginas, bibliografía, agradecimientos, Créditos y un índice alfabético en 36 páginas. ${ }^{1}$ El autor se pregunta "¿Por qué el mundo es cómo es? Quiero analizar cómo la Tierra nos hizo". Como un libro de historia, la obra empieza con los procesos geológicos que dieron lugar a los océanos y los continentes, a la vida orgánica; y sigue con los homínidos antecesores del hombre moderno, los recursos naturales y su aprovechamiento y la agricultura. Todos ellos elementos que son parte de la historia de la evolución de la humanidad y que incluyen estudios de las ciencias recientes de la geología y la antropología, originadas apenas en el siglo XIX, para dar cuenta de la historia humana.

Hay publicaciones que tratan lo anterior, con tres o más autores diferentes, de acuerdo con su especialidad. El mérito de Lewis Darnell consiste en explicar esta historia por el solo. Enlaza el desarrollo del hombre actual y sus antecesores en el ambiente geológico. Explica que el hombre moderno tiene unos 150,000 a 200,000 años en la Tierra; unos millones de años atrás los antepasados del hombre tenían rasgos completamente diferentes, como se observa en los fósiles estudiados, un ejemplo es la célebre Lucy descubierta en 1974 en Etiopía, donde vivió cerca de 3,500,000 años atrás.

Las condiciones geológicas condicionaron la evolución de los organismos, incluso las extinciones masivas, una de ellas definió el límite Paleozoico-Mesozoico, hace 250,000,000 de años, en el antiguo continente de Pangea, donde el 70\% de las especies terrestres y las $90 \%$ de las marinas se extinguieron. Después de 10,000,000 de años hubo una recuperación, según explica Lewis Darnell. Otra gran extinción representa la frontera entre el Mesozoico y el Cenozoico hace unos 65,000,000 de años con la desaparición de los dinosaurios junto con miles de especies marinas y terrestres. Esto significó el desarrollo de los mamíferos a lo largo de decenas de millones de años.

${ }^{1}$ En publicación posterior la obra aparece con el título Origins: How Earth's History Shaped Human History. New York: Hachette Book Group. La versión traducida al español Orígenes. Cómo la historia de la Tierra determina la historia de la humanidad. (2019). México: Debate, motiva a señalar que este título muestra un sesgo determinista que no refleja la perspectiva dialéctica del autor. Cabe destacar que, con el título original, la obra se ha traducido a los idiomas con mayor número de hablantes en el mundo. 


\section{$122 \square$ RESEÑAS}

La formación de la gran fosa tectónica de Rift del oriente de África a lo largo de los últimos 30,000,000 de años originó condiciones climáticas y tectónicas únicas, dice el autor, que permitieron progresar la evolución de una rama de los primates que dio origen al ser humano. También la abertura de la cuenca del mar Mediterráneo hace 5,300,000 de años, y el proceso posterior de reducción por el movimiento del continente africano hacia Eurasia, propició en esta región las condiciones favorables para el desarrollo de una pródiga vida y la profusa navegación, donde el comercio acercó y expandió a diferentes culturas. En este lapso de la historia pasaron 3,000,000 de años entre el desarrollo de los homínidos y los 3,000 años atrás cuando los humanos fundieron el primer cobre.

Otro ejemplo de los cambios en la naturaleza que influyeron en las prácticas de la humanidad fueron los procesos que originaron a Inglaterra, a finales de la última glaciación, 12,000 años atrás, con el consecuente ascenso del nivel del mar de unos 130 $\mathrm{m}$, lo que convirtió a esa región en una isla separada de Francia. Los habitantes que se asentaron desde Stonehenge enfrentaron diversas invasiones de pueblos establecidos alrededor, reforzando el sentimiento de unidad por su territorio insular. Durante decenas de miles de años antes, hace 40,000 años, se explica cómo el hombre pasó de la península de Indochina a Nueva Guinea y Australia. Y en América, las migraciones ocurrieron por la costa occidental, atravesando desde Alaska al istmo de Panamá y a Suramérica hace más de 12,500 años, todo ello expandiendo la especie humana, propiciando cambios genéticos de las especies esparcidas y domesticadas.

Se han estudiado eventos extraordinarios del pasado, cómo los cambios climáticos, el último fue el fin de la glaciación, de 18,000 a 12,000 años antes. En el territorio que comprende los Estados Unidos y Canadá, el lago Agassiz cubría una superficie de $500,000 \mathrm{~km}^{2}$ cuando los bruscos cambios de temperatura lo reventaron (13,000 años), causando una gran inundación hacia el río Mackenzie, que desemboca al Ártico, provocando un ascenso el nivel de mar que afectó a la antigua costa norte de Canadá, proceso que modificó las corrientes marinas.

La variabilidad climática provocada por cambios geológicos influyó en el desarrollo de los humanos. La retirada de los glaciares favoreció que la agricultura fuera propicia simultáneamente en el mundo, los datos actuales consideran que el trigo y la cebada fueron cultivados 11,000 años atrás en Turquía y después en Mesopotamia. Hubo cultivos de arroz en China, maíz en Mesoamérica y papa en los Andes desde hace 9,000-7,000 años y siguió asociándose con otros cultivos domesticados en años posteriores. Más tarde, durante la Pequeña Edad de Hielo de mediados del siglo XIV a mediados XIX transcurrió un cambio climático que fomentó las epidemias, como la peste bubónica, que causó en cinco años la muerte de un tercio de la población de Europa y China; así como enormes pérdidas en la producción alrededor del mundo. No obstante, hubo ventajas que beneficiaron a los sobrevivientes y generaciones siguientes, como la mejor alimentación de los trabajadores del campo y artesanos ante la menor población que debían mantener. 
El autor muestra un ejemplo de la influencia del conocimiento de los vientos y corrientes marinas, el viaje de Colón a las Bahamas y al Caribe y el regreso a Europa fue posible gracias al conocimiento de las corrientes de vientos que favorecían la navegación, sin los conocimientos adquiridos antes y durante la expedición hubiera sido imposible la travesía que transformó la historia mundial.

En esta obra se destacan numerosos hechos geográficos-geológicos que se conjugaron con saltos en el desarrollo de la humanidad. Lo anterior es una breve introducción al texto de Dartnell, el cual se apoya en más de 320 publicaciones científicas y llama la atención que más del $85 \%$ de las citas son de los últimos 20 años. Cabe reflexionar acerca de la enorme información novedosa sobre las culturas humanas, esperamos que esta historia siga enriqueciéndose año con año. Es muy significante que casi toda la información reunida en el texto de Dartnell se haya producido en un tiempo tan breve, cuya amena lectura, abre una perspectiva muy amplia para desentrañar y conocer mejor nuestro planeta y analizar los históricos problemas globales asociados, como el crecimiento de la población, el cambio climático global y otros relacionados, como el estudio de los detonantes de las epidemias actuales.

Orígenes es un libro de ciencia-divulgación accesible a todo público, en especial para quienes se interesan por disciplinas como la Historia, Antropología, Geografía, Geología, Ecología y otras. Hay que tomar en cuenta que hacia la mitad del presente siglo el conocimiento de estos temas debe ser superado considerablemente, ya que si continúa el cambio de la temperatura con sus efectos de aumento del nivel del mar y la retirada de los glaciares en ese umbral, tendremos una geografía muy diferente que estudiar. 